\title{
ANALISIS ERGONOMI PADA PRAKTIK MEMELIHARA RODA DAN BAN MENGGUNAKAN METODE REBA
}

\author{
Friska Pakpahan", Wowo S. Kuswana², Ridwan A.M. Noor ${ }^{3}$ \\ Departemen Pendidikan Teknik Mesin \\ Universitas Pendidikan Indonesia \\ Jl. Dr. Setiabudhi No. 207 Bandung 40154 \\ friska288@gmail.com
}

\begin{abstract}
ABSTRAK
Penelitian ini bertujuan mengetahui tingkat resiko ergonomi otot-rangka siswa dalam melakukan praktik. Metode yang digunakan untuk menganalisis posisi tubuh adalah Rapid Entire Body Assesment (REBA). Penelitian ini dilakukan dengan observasi terstruktur antropometri siswa untuk mengkategorikan tubuh lalu dianalisa menggunakan metode REBA. Metode REBA menganalisis posisi leher menekuk, posisi punggung membungkuk, posisi kaki berjongkok, Posisi lengan atas dinaikkan, posisi lengan bawah menekuk, posisi pergelangan tangan menekuk. Beban angkat dari roda dan ban sepuluh kilogram. Pegangan genggaman tangan tidak bisa diterima karena pegangan tidak sesuai. Aktivitas kaki berlebihan karena jongkok lebih dari satu menit. Hasil nilai REBA antropometri persentil 5 sebesar 10, berarti tingkat resiko cidera tinggi dan tindakan perlu dilakukan perubahan untuk mengurangi resiko. Hasil nilai REBA antropometri persentil 50 dan 95 sebesar 12 berarti tingkat resiko cidera sangat tinggi dan kondisi sangat berbahaya dan tindakan perlu saat ini juga dilakukan perubahan untuk mengurangi resiko. Kendaraan yang tidak bisa diatur ketinggiannya membuat kondisi praktik rentan terhadap cidera. Sebaiknya menggunakan alat bantu car lift untuk mengatur ketinggian kendaraan sesuai dengan antropometri.
\end{abstract}

Kata kunci: ergonomi, antropometri, rapid entire body assesment, produktif

\section{PENDAHULUAN}

Siswa praktik tanpa menggunakan alat bantu car lift untuk mengatur ketinggian kendaraan sehingga dimensi tubuh yang menyesuaikan dengan ketinggian mobil (Hardianto, I. \& Yassierli, 2014). Penyesuaian mobil yang tidak bisa diatur ketinggiannya membuat posisi leher siswa menekuk, posisi punggung membungkuk, posisi kaki berjongkok dan harus bertumpu didua kaki atau satu kaki. Posisi lengan atas dinaikkan, posisi lengan bawah menekuk, posisi pergelangan tangan menekuk. Siswa mengangkat berat roda dan ban, menggenggam roda saat dipasang, dan aktifitas berulang. Diskusi awal kepada siswa kelas XI mengenai praktik memelihara roda dan ban. Siswa mengemukakan keluhan di otot-otot skeletal. Keluhan di otot-rangka (skeletal) merupakan faktor risiko dari ergonomi. Keluhan-keluhan yang dirasakan pada nyeri punggung, nyeri leher, nyeri pada pergelangan tangan, siku dan kaki. Tubuh bagian atas dan bawah terutama punggung, lengan dan kaki dirasakan sangat terasa sakit (Pheasant, 2003). Cidera akibat gangguan otot-rangka manusia dapat terjadi dari faktor praktik dan faktor siswa. Faktor praktik yang canggung (posisi tubuh), posisi kerja statis, peregangan otot yang berlebihan,

\footnotetext{
${ }^{1}$ Mahasiswa Departemen Pendidikan Teknik Mesin FPTK UPI

2 Dosen Departemen Pendidikan Teknik Mesin FPTK UPI

${ }^{3}$ Dosen Departemen Pendidikan Teknik Mesin FPTK UPI
} 
aktifitas berulang, force/load (beban angkat), frekuensi, durasi dan alat perangkai/genggaman. Faktor siswa yakni postur tubuh (ukuran), usia, dan jenis kelamin (Nurmianto, 2004). Analisis yang peneliti lakukan pada faktor siswa hanya pada postur tubuh (ukuran). Faktor siswa dalam penelitian ini diambil dari postur tubuh berdasarkan antropometri siswa. Analisis Pekerjaan terdiri dari posisi tubuh, beban angkat, genggaman, aktifitas berulang, durasi dan frekuensi. Analisis risiko ergonomi yang dipakai untuk penelitian ini adalah metode rapid entire body assesment (REBA, 2004).

Metode REBA dibutuhkan untuk pengumpulan data posisi tubuh dari analisis ergonomi untuk gambaran tingkat risiko ergonomi. Jika didapatkan skor akhir 1-2, maka tingkat risiko ergonomi yang dihadapi oleh siswa adalah Acceptable/dapat diterima, jika didapatkan skor akhir 3-4, maka Investigate Further/perlu penyelidikan lebih lanjut, jika didapatkan skor akhir 5-6, maka Investigate Further and change soon/perlu investigasi lebih lanjut dan perubahan segera dilakukan, dan jika skor 7 berarti Investigate and change soon/penyelidikan dan perubahan segera dilakukan.

\section{METODOLOGI PENELITIAN}

Metode penelitian yang digunakan pada penelitian ini yaitu deskriftif. Penelitian ini dilakukan dalam praktik kerja memelihara roda dan ban pada siswa kelas XI TKR SMK Negeri 6 Bandung tahun ajaran 2015/2016. Jumlah sampel dalam penelitian ini sebanyak $20 \%$ x seluruh jumlah populasi $=20 \% \times 173$ siswa $=34$ siswa. Jika di dalam satu kelas diambil antara 6 siswa dari 4 kelas dan 5 siswa dari 2 kelas, maka sampel dapat diambil dari 6 kelas. Jumlah $\{(6$ siswa $\times 4$ kelas $)+(5$ siswa $\times 2$ kelas $)\}=34$ siswa.

Pengumpulan data menggunakan antropometri pada siswa kelas XI TKR SMK Negeri 6 Bandung. Data antropometri digunakan untuk mengklasifikasikan postur tubuh dalam proses analisis dengan metode REBA. Pengumpulan data REBA yaitu dengan wawancara dan dokumen. Wawancara untuk mengetahui fenomena awal yang terjadi pada tubuh siswa. Wawancara dilakukan secara terbuka dan terjadi diskusi mengenai keluhan otot-rangka. Dokumen dalam penelitian ini mengambil rekaman video dan foto untuk menentukan sudut-sudut kerja dari tubuh siswa ketika melakukan pekerjaan praktik memelihara roda dan ban. 


\section{HASIL PENELITIAN}

Posisi tubuh siswa antropometri data persentil 5 (Tabel 1 dan 2) yaitu posisi leher menekuk $10^{\circ}$ ditambah leher miring kekiri maka skor posisi leher 2, posisi punggung membungkuk $30^{\circ}$ maka skor posisi punggung 3, posisi kaki berjongkok bertumpu oleh 2 kaki ditambah kaki ditekuk $150^{\circ}$ maka skor posisi kaki 3, posisi lengan atas menekuk $25^{\circ}$ ditambah bahu dinaikkan maka skor posisi lengan atas 3, posisi lengan bawah menekuk $106^{\circ}$ maka skor posisi lengan bawah 2 , posisi pergelangan tangan menekuk $23^{\circ}$ maka skor posisi pergelangan tangan 2. Berat beban yang diangkat yaitu berat roda dan ban $10 \mathrm{~kg}$ maka skor berat beban 1. Pegangan genggaman fair yaitu pegangan tangan bisa diterima tapi tidak ideal karena tangan kiri dan kanan tidak sejajar maka skor pegangan genggaman 1. aktivitas lebih bagian tubuh statis ditahan lebih dari 1 menit yaitu kaki ditekuk lebih dari 1 menit maka skor aktivitas 1 .

Tabel 1. Analisis REBA skor a sampel antropometri tubuh persentil 5

\begin{tabular}{clcl}
\hline No & \multicolumn{1}{c}{ Postur } & Derajat & \multicolumn{1}{c}{ Skor } \\
\hline 1 & Leher & $10^{\circ}$ & 1 Ditambah +1 leher miring = 2 \\
2 & Punggung & $30^{\circ}$ & $3+0$ punggung tidak miring = 3 \\
3 & Kaki & 2 kaki & $1+2$ ditekuk $<60=3$ \\
\multicolumn{2}{r}{ Jumlah skor A+Beban angkat $10 \mathrm{~kg}$} & $6+1=7$ \\
\hline
\end{tabular}

Tabel 2. Analisis REBA skor b sampel antropometri tubuh persentil 5

\begin{tabular}{clcl}
\hline No & \multicolumn{1}{c}{ Postur } & Derajat & \multicolumn{1}{c}{ Skor } \\
\hline 1 & Lengan atas & $25^{\circ}$ & $2+1$ bahu dinaikkan=3 \\
2 & Lengan bawah & $106^{\circ}$ & 2 \\
3 & $\begin{array}{l}\text { Pergelangan } \\
\text { tangan }\end{array}$ & $23^{\circ}$ & $\begin{array}{l}2+0 \text { tidak terdapat putaran } \\
\text { dipergelangan tangan=2 }\end{array}$ \\
& Jumlah skor B + Genggaman fair & $5+1=6$ \\
\hline
\end{tabular}

Siswa pada antropometri tubuh data persentil 5 (Tabel 3 dan 4) memiliki nilai REBA sebesar 10 memiliki tingkat risiko tinggi dan berbahaya dan perlu dilakukan perubahan atau penggantian. Posisi tubuh siswa antropometri data persentil 50 yaitu posisi leher menekuk $40^{\circ}$ ditambah leher berputar dan miring maka skor posisi leher 3 , posisi punggung membungkuk $30^{\circ}$ ditambah leher punggung berputar dan miring maka skor posisi pungggung 4, posisi kaki berjongkok bertumpu oleh 1 kaki ditambah kaki ditekuk 
$140^{\circ}$ maka skor posisi kaki 4 , posisi lengan atas menekuk $10^{\circ}$ ditambah bahu dinaikkan maka skor lengan atas dikurangi karena tangan ditopang oleh lutut kaki maka skor posisi lengan atas 1 , posisi lengan bawah menekuk $120^{\circ}$ maka skor posisi lengan bawah 2 , posisi pergelangan tangan menekuk $10^{\circ}$ ditambah terjadi putaran pada pergelangan tangan maka skor posisi pergelangan tangan 2. Berat beban yang diangkat adalah berat roda dan ban $10 \mathrm{~kg}$ maka skor berat beban 1. pegangan genggaman unaccepttable yaitu pegangan tangan dipaksakan dan pegangan tangan tidak aman karena tangan mencengkram lubang-lubang logam pada roda maka skor pegangan genggaman 3. aktivitas lebih bagian tubuh statis ditahan lebih dari 1 menit yaitu kaki ditekuk lebih dari 1 menit maka skor aktivitas 1 .

Tabel 3. Analisis REA Skor A Sampel Antropometri Tubuh Persentil 50

\begin{tabular}{clcl}
\hline No & \multicolumn{1}{c}{ Postur } & Derajat & \multicolumn{1}{c}{ Skor } \\
\hline 1 & Lengan atas & $10^{\circ}$ & $1+1$ bahu dinaikan -1 ditopang kaki $=$ \\
& & 1 \\
2 & Lengan bawah & $120^{\circ}$ & 2 \\
3 & Pergelangan tangan & $10^{\circ}$ & $1+1$ terjadi putaran pada pergelangan \\
& & tangan $=2$ \\
Jumlah skor B+ Genggaman Unaceptable & $2+3=5$ \\
\hline
\end{tabular}

Tabel 4. Analisis REBA Skor B Sampel Antropometri Tubuh Persentil 50

\begin{tabular}{|c|c|c|c|}
\hline No & Postur & Derajat & Skor \\
\hline 1 & Leher & $40^{\circ}$ & $\begin{array}{l}2 \text { Ditambah }+1 \text { leher berputar dan } \\
\text { miring kearah bawah }=3\end{array}$ \\
\hline 2 & Punggung & $30^{\circ}$ & $\begin{array}{l}3 \text { Ditambah }+1 \text { punggung berputar dan } \\
\text { miring kearah bawah }=4\end{array}$ \\
\hline 3 & Kaki & 1 kaki \& $140^{\circ}$ & $2+2$ ditekuk $<60^{\circ}=4$ \\
\hline \multicolumn{3}{|c|}{ Jumlah skor A + Beban angkat 10kg } & $9+1=10$ \\
\hline
\end{tabular}

Hasil penilaian (Tabel 5 dan 6) diketahui bahwa siswa pada antropometri tubuh data persentil 50 memiliki nilai REBA sebesar 12 memiliki tingkat risiko sangat tinggi dan kondisi sangat berbahaya dan perlu saat ini juga dilakukan perubahan atau penggantian. Posisi tubuh siswa antropometri data persentil 95 yaitu posisi leher menekuk $43^{\circ}$ ditambah leher miring maka skor posisi leher 3, posisi punggung membungkuk $40^{\circ}$ ditambah punggung miring maka skor posisi punggung 4, posisi kaki berjongkok bertumpu oleh 1 kaki ditambah kaki ditekuk $130^{\circ}$ maka skor posisi kaki 4, posisi lengan atas menekuk $10^{\circ}$ ditambah bahu dinaikkan maka skor lengan atas 2, posisi lengan bawah menekuk $128^{\circ}$ maka skor posisi lengan bawah 2 , posisi pergelangan tangan menekuk $18^{\circ}$ ditambah terjadi putaran pada pergelangan tangan maka skor posisi pergelangan tangan 3. Berat beban yang diangkat adalah berat roda dan ban 10kg maka skor berat beban 1. pegangan genggaman unaccepttable yaitu pegangan tangan dipaksakan dan pegangan tangan tidak aman karena 
tangan mencengkram lubang-lubang logam pada roda maka skor pegangan genggaman 3 . aktivitas lebih bagian tubuh statis ditahan lebih dari 1 menit yaitu kaki ditekuk lebih dari 1 menit maka skor aktivitas 1 .

Tabel 5. Analisis REBA Skor A Antropometri Tubuh Persentil 95

\begin{tabular}{clcl}
\hline No & \multicolumn{1}{c}{ Postur } & Derajat & \multicolumn{1}{c}{ Skor } \\
\hline 1 & Leher & $43^{\circ}$ & $2+1$ leher berputar $=3$ \\
2 & Punggung & $40^{\circ}$ & $3+1$ punggung miring $=4$ \\
3 & Kaki & 1 kaki \& $130^{\circ}$ & $2+2$ ditekuk $=4$ \\
Jumlah skor A + Beban angkat $10 \mathrm{~kg}$ & $9+1=10$ \\
\hline
\end{tabular}

Tabel 6. Analisis REBA Skor B Antropometri Tubuh Persentil 95

\begin{tabular}{clcl}
\hline No & \multicolumn{1}{c}{ Postur } & Derajat & \multicolumn{1}{c}{ Skor } \\
\hline 1 & Lengan atas & $10^{\circ}$ & $1+1$ bahu dinaikkan $=2$ \\
2 & Lengan bawah & $128^{\circ}$ & 2 \\
3 & $\begin{array}{l}\text { Pergelangan } \\
\text { tangan }\end{array}$ & $18^{\circ}$ & $\begin{array}{l}2+1 \text { terjadi putaran pada pergelangan } \\
\text { tangan }=3\end{array}$ \\
Jumlah skor B+ Genggaman Unaceptable & $4+3=7$
\end{tabular}

Hasil penilaian diketahui bahwa siswa pada antropometri tubuh data persentil 95 memiliki nilai REBA sebesar 12 memiliki tingkat risiko sangat tinggi dan kondisi sangat berbahaya dan perlu saat ini juga dilakukan perubahan atau penggantian.

\section{PEMBAHASAN}

Siswa melakukan praktik memelihara roda dan ban merupakan salah satu praktik dengan penanganan secara manual. Manual tanpa menggunakan alat bantu car lift untuk mengatur ketinggian kendaraan sehingga dimensi tubuh yang menyesuaikan dengan ketinggian kendaraan (Mcatamney \& Higneet, 2000). Penyesuaian benda kerja yang tidak bisa diatur ketinggiannya membuat posisi leher siswa menekuk diperparah harus leher miring kekiri dan kekanan serta leher memutar kekiri dan kekanan (Wignjosoebroto, 2003). Posisi punggung membungkuk diperparah punggung miring kekiri dan kekanan serta punggung memutar kekiri dan kekanan. Posisi kaki berjongkok dan tubuh rendah bertumpu pada dua kaki sedangkan tubuh sedang dan tinggi harus bertumpu disatu kaki. Posisi lengan atas menekuk diperparah bahu harus dinaikkan, posisi lengan bawah menekuk, posisi pergelangan tangan menekuk diperparah pergelangan miring kekiri dan 
kekanan serta memutar (Wu and Hsieh, 2010). Beban angkat dari berat roda dan ban sepuluh kilogram. Pegangan genggaman tangan tubuh rendah masih diterima sedangkan tubuh sedang dan tinggi tidak bisa diterima karena pegangan tidak sesuai. Aktivitas kaki berlebihan karena jongkok lebih dari satu menit (Kuswana, 2014).

Antropometri siswa bertubuh rendah memiliki tingkat risiko tinggi dan berbahaya. Kondisi berbahaya ini perlu dilakukan perubahan dan penggantian posisi tubuh. Antropometri siswa bertubuh sedang dan tinggi memiliki tingkat risiko sangat tinggi dan sangat berbahaya (Kuswana, 2015). Kondisi sangat berbahaya ini perlu saat ini juga dilakukan perubahan atau penggantian posisi tubuh saat praktik.

\section{KESIMPULAN}

Penelitian ini dapat disimpulkan bahwa tingkat resiko cidera sangat tinggi dan kondisi sangat berbahaya. Hal tersebut perlu segera ada tindakan yang segera dilakukan dan perubahan untuk mengurangi resiko. Kendaraan yang tidak bisa diatur ketinggiannya membuat kondisi praktik rentan terhadap cidera. Untuk mengatasinya dapat digunakan alat bantu car lift untuk mengatur ketinggian kendaraan sesuai dengan antropometri.

\section{DAFTAR PUSTAKA}

Hardianto, I. \& Yassierli. (2014). Ergonomi Suatu Pengantar. Bandung: PT. Remaja Rosdakarya.

Kuswana, S. W. (2014). Ergonomi dan K3 (Kesehatan, Keselamatan Kerja). Bandung:Remaja Rosdakarya.

Kuswana, S. W. (2015). Antropometri Terapan untuk Perancangan Sistem Kerja. Bandung: Remaja Rosdakarya.

Mcatamney, L. \& Higneet, S. (2000). Rapid Entire Body Assessment. [online]. diakses dari: http: //www.researchgate.net/publication/1260377

Nurmianto, E. (2004). Ergonomi Konsep Dasar dan Aplikasinya. Surabaya: Institut Teknologi Sepuluh Nopember

Pheasant, S. (2003). Body Space Anthropometry, Ergonomic, and The Design Work. Philadelphia: Taylor \& Francis

REBA (2004). Reba Scoring. [online]. diakses dari: http://ergo.human.cornell.edu

Wignjosoebroto, S. (2003). Ergonomi Studi Gerak dan Waktu. Surabaya: Guna Widya

Wu, S. P. \& Hsieh, M.F. (2010). Ergonomic Study Of Heavy Truck and Bus Tire Maintenance Workers. Journal Of Occupational Safety And Health. 